\title{
Updated status of whiteflies (Hemiptera: Aleyrodidae) in Jordan with emphasis on the Bemisia tabaci species complex
}

\author{
Actualización del estatus de las moscas blancas (Hemiptera: Aleyrodidae) en Jordania \\ con énfasis en el complejo Bemisia tabaci
}

\author{
IHAB GHABEISH ${ }^{1}$; MAIS SWEISS ${ }^{2}$; GHANDI ANFOKA ${ }^{3}$
}

\begin{abstract}
${ }^{1} \mathrm{Ph}$. D. Entomology Al-Balqa Applied University, As-Shoubak University College, Department of Agricultural Sciences, Al-Shoubk 711910, Jordan, ghabeish@bau.edu.jo, https://orcid.org/0000-0002-3985-827X. 2 Ph. D. Algae and Plant Biotechnology, Al-Balqa Applied University, Faculty of Agricultural Technology, Department of Biotechnology, Al-Salt 19117, Jordan, m.swies@bau.edu.jo, https://orcid.org/0000-0002-1512-9224. 3 Ph. D. Plant Virology, Al-Balqa Applied University, Faculty of Agricultural Technology, Department of Biotechnology, Al-Salt 19117, Jordan, anfoka@bau.edu.jo, https://orcid. org/0000-0002-7826-356X.
\end{abstract}

\section{Corresponding author}

Mais Sweiss. Ph. D. Algae and Plant Biotechnology, Al-Balqa Applied University, Faculty of Agricultural Technology, Department of Biotechnology, Al-Salt 19117, Jordan, m.swies@ bau.edu.jo, https://orcid.org/0000-0002-15129224.

\section{Suggested citation}

GHABEISH, I.; SWEISS, M.; ANFOKA, G. 2021. The updated status of whiteflies (Hemiptera: Aleyrodidae) in Jordan with emphasis on the Bemisia tabaci species complex. Revista Colombiana de Entomología 47 (1): e8944. https://doi.org/10.25100/socolen.v47i1.8944

Received: 21-Feb-2020

Accepted: 01-Sep-2020

Published: 21-May-2021

Revista Colombiana de Entomología ISSN (Print): 0120-0488

ISSN (On Line): 2665-4385

https://revistacolombianaentomologia.univalle.edu.co

Open access

(c) (1) (2) (2) BY-NC-SA 4.0

Publishers: Sociedad Colombiana de Entomología SOCOLEN (Bogotá, D. C., Colombia) https://www.socolen.org.co

Universidad del Valle (Cali, Colombia)

https://www.univalle.edu.co

(C) 2021 Sociedad Colombiana de Entomología SOCOLEN y Universidad del Valle - Univalle
Abstract: Whiteflies are economically important plant pests that cause damage to crops worldwide. This study aimed to update the status of whiteflies in Jordan by combining the classical morphological identification and the DNA markers using the mitochondrial cytochrome oxidase I ( $\mathrm{mtCOI}$ ) gene. Over the course of three consecutive years, 111 whiteflies were collected from different geographical regions and different plant hosts in Jordan. The results showed that, in addition to Bemisia tabaci, another nine different whitefly species were identified, including two species that were recorded for the first time in Jordan: Africaleurodes coffeacola, and Tetraleurodes neemani. A special focus has been given to economically important plant pests like the B. tabaci species complex. Three different diagnostic techniques were used to identify $B$. tabaci putative species based on $m t C O I$ gene. All the collected samples of $B$. tabaci species complex were identified as Middle East-Asia Minor 1 (MEAM1) putative species.

Keywords: Molecular identification, whiteflies, pests, MEAM1, mtCOI, Bemisia tabaci.

Resumen: Las moscas blancas son plagas de plantas de importancia económica, que causan daños a cultivos en todo el mundo. Este estudio tuvo como objetivo actualizar el estado de conocimiento sobre las moscas blancas en Jordania, combinando la identificación morfológica clásica y la tecnica del gen de citocromo oxidasa I mitocondrial ( $m t C O I$ ) como un marcador de ADN. En el transcurso de tres años consecutivos se recolectaron 111 moscas blancas de diferentes regiones geográficas, y de diferentes plantas hospederas. Los resultados mostraron que, además de Bemisia tabaci, existen nueve especies diferentes de mosca blanca; incluso se registraron por primera vez en Jordania dos especies: Africaleurodes coffeacola y Tetraleurodes neemani. Se hizo especial énfasis en el complejo de especies de $B$. tabaci por su importancia económica. Se utilizaron tres técnicas de diagnóstico diferentes para identificar especies cercanas a $B$. tabaci basadas en el gen $m t C O I$. Sin embargo, todas las muestras recolectadas del complejo de especies de $B$. tabaci se identificaron como especies del complejo de Oriente Medio-Asia Menor 1 (MEAM1).

Palabras clave: Identificación molecular, moscas blancas, plagas, MEAM1, mtCOI, Bemisia tabaci.

\section{Introduction}

Whiteflies (Hemiptera: Aleyrodidae) are insects that feed on plants by sucking large quantities of sap. Sucking plant sap can cause early wilting, stunted growth, premature defoliation, and eventually yield loss (Shukla et al. 2016). In addition, whiteflies secrete honeydew that causes sooty mould growth on plants leaves and fruits and reduces their market values. Whiteflies have also been reported to act as vectors for plant viruses (Byrne and Bellows 1991; Jones 2003; Shukla et al. 2016). There are around 1556 species of whiteflies in 161 genera (Martin 2004), however, only a few acts as a vector for plant viruses. Bemisia tabaci (Gennadius, 1889) transmits around 212 viruses from five genera Begomovirus, Crinivirus, Ipomovirus, Carlavirus, and Torradovirus (Navas-Castillo et al. 2011; Polston et al. 2014). Trialeurodes vaporariorum (Westwood, 1856), the greenhouse whitefly, transmits viruses from two genera Crinivirus and Torradovirus (Navas-Castillo et 
al. 2011). Trialeurodes abutiloneus (Haldeman, 1850, the banded-winged whitefly) transmits viruses of the genera Crinivirus and Torradovirus (Mlynarek and Labbé 2018). Bemisia afer (sensu lato) transmits the sweet potato chlorotic stunt virus of Crinivirus (Gamarra et al. 2010; Navas-Castillo et al. 2011). Trialeurodes ricini (Misra, 1924, the castor bean whitefly) could be a vector for the tomato yellow leaf curl virus (TYLCV) in Egypt (Idriss et al. 1997).

It is important to study the diversity of the different whitefly populations to be able to manage and design effective control methods for these pests. During the period between 1985-1994, a study was conducted to identify the whitefly species in Jordan and report some of their natural enemies. Eleven species were morphologically identified based on the characteristics of their pupa. These species were Acaudaleyrodes citri (Priesner and Hosny, 1934) Aleurocanthus zizyphi (Priesner and Hosny, 1934), Aleurolobus niloticus (Priesner and Hosny, 1934), Aleurolobus olivinus (Silvestri, 1911), Aleyrodes proletella (Linnaeus, 1758), Aleyrodes singularis (Danzig, 1964), B. tabaci, Siphoninus phillyreae (Haliday, 1835), Trialeurodes lauri (Signoret, 1882), T. ricini (Misra), and T. vaporariorum (Allawi 1994). In addition to the aforementioned whiteflies, Acaudaleyrodes rachipora (Singh, 1931, Babul whitefly) and Aleurolobus marlatti (Quaintance, 1903) have been also reported in Jordan (Ghahari et al. 2009). Nonetheless, the classical taxonomy of whiteflies based on the morphology of the puparium (fourth instar) is complicated since the intraspecific variability in the morphology such as the size, shape, number of setae and papillae, the perianal structure, and the body size, can be affected by the variations in the environment (Ko et al. 2005).

The "superbug" Bemisia tabaci is one of the most damaging insects known in the agricultural world (Barinaga 1993). It is broadly polyphagous, feeding on an estimated 600 plant species (European and Mediterranean Plant Protection Organization 2004). In Jordan, around 339 plant species in 64 families were reported as hosts for B. tabaci (Sharaf and Allawi 1980). B. tabaci was described as a species complex having many putative species that are morphologically indistinguishable (Dinsdale et al. 2010). Reliable morphological markers which can distinguish between the different genetic groups of the B. tabaci species complex are not known (Rosell et al. 1997). As a result, the molecular markers can be an important tool to study the variation in populations of the species complex of B. tabaci (Cervera et al. 2000).

Phylogenetic studies comparing the sequence of a region of the DNA such as the 16S ribosomal subunit (Frohlich et al. 1999), ribosomal internal transcribed spacer-1 ITS1 sequence (De Barro et al. 2000; Wu et al. 2003), and mitochondrial cytochrome oxidase I (mtCOI) gene (Frohlich et al. 1999; Kirk et al. 2000; Luo et al. 2002) have been carried out to determine the genetic relationships among $B$. tabaci species complex. Dinsdale et al. (2010) performed a study based on the analysis of sequence pairwise divergence and the Bayesian phylogenetic analysis of $m t C O I$ gene to study the $B$. tabaci species complex. Based on the genetic species concept to distinguish between the putative species, besides the mating experiment, they concluded that $B$. tabaci is a species complex consisting of 11 groups containing 24 species (Dinsdale et al. 2010). Boykin (2014) concluded that B. tabaci species complex seems to be made up of more than one species. This was based on data obtained from mating compatibility (Xu et al. 2010; Liu et al. 2012; Sun et al. 2011), genomes (Wang et al. 2011; Wang et al. 2013), and mtCOI phylogenetic analysis (Boykin et al. 2007; Dinsdale et al. 2010; Boykin et al. 2012; Tay et al. 2012).

This study is concerned with the characterization of the most invasive putative species of $B$. tabaci, which are the Middle East-Asia Minor 1 (MEAM1; previously described as biotype B), and the Mediterranean putative species (MED; previously known as biotype Q). Both of them are important from a biosecurity perspective, as they are resistant to a wide range of insecticides (Prabhaker et al. 1988), globally invasive, and cause huge economic losses (Oliveira et al. 2001; Boykin et al. 2012). MEAM1 invaded at least 54 countries around the world (Broadbent et al. 1989; Cheek and MacDonald 1994, De Barro et al. 2011). Whilst MED putative species invaded at least ten countries worldwide such as United States, China, Japan, and New Zealand (De Barro et al. 2011).

Since the putative species MEAM1 and MED of $B$. tabaci are morphologically indistinguishable (Liu et al. 2016) many studies were performed to understand their dispersal behaviour, insecticide resistance, plant-host preference, endosymbiont composition, fecundity, and efficiency in plant viruses transmission (Brown et al. 1995a; Horowitz et al. 2005; Bing et al. 2012; Liu et al. 2016; Shi et al. 2018; Watanabe et al. 2019; Yang et al. 2020). MED putative species is characterized by its resistance to a wide variety of insecticides (Nauen et al. 2002; Horowitz et al. 2005; Nauen and Denholm 2005; Ghanim and Kontsedalov 2007; Yang et al. 2013).

In Jordan, the presence of MEAM1 was documented by (Brown et al. 1995b). Subsequently, a study carried out using RAPD-PCR to identify the B. tabaci species complex in Jordan found MEAM1 and the New World putative species that is formerly known as biotype A (Sharaf and Hasan 2003). The highly invasive putative species MED was not reported in Jordan before, although it was reported in neighbour countries such as Syria, Palestine/Israel, and Egypt (Horowitz et al. 2003; Khasdan et al. 2005; De Barro et al. 2011). This work aims to combine the classical morphological identification method with the DNA barcoding marker (mtCOI) for the first time to identify and document the presence of the whitefly species in Jordan.

\section{Materials and methods}

Sample collection and morphological identification. To learn more about the status of whiteflies in Jordan, around 111 different whiteflies samples were collected during the years 2009-2012 (Table 1). Of the 111 samples, around 85 were of $B$. tabaci. The samples of $B$. tabaci were collected from more than 23 hosts of cultivated plants (e.g. tomato, cucumber, cauliflower, okra, watermelon, eggplant, and squash), non-cultivated (e.g. basil), and non-food crops (e.g. cotton, poinsettia, and Lantana camara L.). The host plants were grown in both greenhouses and open fields in different geographical regions in Jordan including the Jordan Valley area $\left(32^{\circ} 19^{\prime} 1.20^{\prime \prime} \mathrm{N} 35^{\circ} 34^{\prime} 7.19^{\prime \prime} \mathrm{E}\right)$, and another six different provinces: Amman (31 $\left.35^{\circ} 1.28^{\prime \prime} \mathrm{N} 36^{\circ} 20^{\prime} 0.06^{\prime} \mathrm{E}\right)$, AL-Balqa'

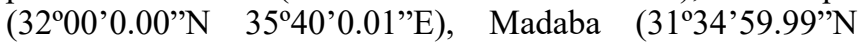
$\left.35^{\circ} 40^{\prime} 0.01^{\prime \prime} \mathrm{E}\right)$, Jerash $\left(32^{\circ} 15^{\prime} 0.00^{\prime \prime} \mathrm{N} \quad 35^{\circ} 55^{\prime} 0.01\right.$ ' $\left.\mathrm{E}\right)$, Ma an (30 $\left.19^{\prime} 59.99^{\prime \prime} \mathrm{N} \quad 36^{\circ} 34^{\prime} 59.99^{\prime \prime} \mathrm{E}\right)$, and Al-Mafraq (32 $19^{\circ} 59.99^{\prime} \mathrm{N} 37^{\circ} 55^{\prime} 0.01^{\prime}$ 'E). Pupal stages were collected and reared until adults emerged. The collected adults were preserved in $70 \%$ ethanol to be subjected to DNA isolation, whilst the empty pupal cases were sent for morphological 
identification by Professor Dan Gerling (Tel Aviv University). Two references for the putative species MEAM1 and MED were kindly provided by Dr Rami Horowitz (the Institute of Plant Protection, Gilat Research Centre).

DNA extraction and amplification of the mtCOI gene. DNA was extracted from a single whitefly adult or pupa for DNA barcoding of the collected samples according to (Cenis et al. 1993) with modifications recommended by (Khasdan et al. 2005). After the DNA extraction, a PCR reaction was performed to amplify $816 \mathrm{bp}$ fragment of the $m t C O I$ gene (Khasdan et al. 2005) with some modifications. The PCR reaction contained around $20 \mathrm{ng}$ total DNA in $1 \mathrm{X}$ buffer, one unit of the Taq DNA polymerase and $0.2 \mu \mathrm{M}$ dNTPs (Promega Corporation, USA), $2.5 \mathrm{mM} \mathrm{MgCl}, 0.4 \mu \mathrm{M}$ of the forward primer C1-J-2195 5 TTGATTTTTTGGTCATCCAGAAGT3 and $0.4 \mu \mathrm{M}$ reverse primer L2-N-3014 5'TCCAATGCACTAATCTGCCATATTA3' (Frohlich et al. 1999). PCR was performed in a PTC200 thermocycler (MJ Research Inc., USA). The PCR program was composed of an initial denaturation at $94{ }^{\circ} \mathrm{C}$ for $3 \mathrm{~min}, 40$ cycles of one min at $94{ }^{\circ} \mathrm{C}$ followed by one min at $52^{\circ} \mathrm{C}$ and one min at $72{ }^{\circ} \mathrm{C}$, and a final extension step at $72{ }^{\circ} \mathrm{C}$ for seven min. The PCR products were analysed on $1 \%$ agarose gel stained with 0.5 $\mu \mathrm{g} / \mathrm{ml}$ of ethidium bromide. A part of the amplified $m t C O I$ gene was sent for sequencing and another part was analysed in the following step.

Cleaved Amplified Polymorphic Sequences (CAPS) for (mtCOI) sequences. To reduce the number of the samples that will be sent for sequencing, two diagnostic techniques were used to distinguish between $B$. tabaci species complex. The first technique was CAPS which distinguishes between MEAM1 and MED putative species that are likely to present in Jordan. To perform CAPS, a part of $m t C O I$ gene, which was amplified in the previous step, was subjected to digestion by restriction endonuclease $V s p I$ according to (Khasdan et al. 2005). Only a short fragment (41 bp) was cut out of MEAM1, while PCR products of MED yielded three fragments of about $436 \mathrm{bp}, 292 \mathrm{bp}$, and $41 \mathrm{bp}$.

Bidirectional PCR amplification of mtCOI fragments. The second diagnostic technique was used to distinguish between $B$. tabaci species complex was the bidirectional PCR (Tsagkarakou et al. 2007). Four primers were used in each PCR reaction. The two outer primers, the forward primer C1-J-2195 (5' TTGATTTTTTGGTCATCCAGAAGT 3`; Frohlich et al. 1999) and the reverse primer tRNA-1576 (5 TATAAATCTTAAATTTACTGCA 3`; Tsagkarakou et al. 2007) they yielded around $879 \mathrm{bp}$ control fragment for all the $B$. tabaci species complex. The two inner primers, LQ 5 ' AAGGGGCCTGAATTTATTG 3`and RB5`CTACTTTGGGTGGAATAAAGTCT $3{ }^{`}$ were designed and tested to distinguish between MEAM1 and MED (Tsagkarakou et al. 2007). In the case of MEAM1 putative species, RB/tRNA1576 primers amplify the $609 \mathrm{bp}$ fragment. Whilst, in the case of MED LQ/C1-J-2195 primers will amplify the 310 bp fragment. If only the control band is obtained, it may indicate that it belongs to another putative species of the B. tabaci such as the New World or other putative species which were known previously as $\mathrm{C}, \mathrm{E}$, and $\mathrm{G}$ biotypes and the exact biotype will be confirmed by the sequencing of the $m t C O I$ gene. The PCR reaction was performed in mostly the same way as above, with the exception that in this reaction, four primers were used and the PCR program was, initial denaturation at $94{ }^{\circ} \mathrm{C}$ for 3 min, 40 cycles of $45 \mathrm{sec}$ at $94{ }^{\circ} \mathrm{C}$, one min at $50{ }^{\circ} \mathrm{C}$ and one min at $72{ }^{\circ} \mathrm{C}$, and a final extension step at $72{ }^{\circ} \mathrm{C}$ for $10 \mathrm{~min}$.

Sequencing and phylogenetic analysis of $\mathrm{mtCOI}$ gene. Representative samples of $B$. tabaci species complex and the other whitefly species were sent for sequencing at Macrogen, (Seoul, South Korea). Analysis of the sequences was performed using MEGA X (Kumar et al. 2018) and the Nucleotide Basic Local Alignment Search Tool (Nucleotide BLAST) service provided by the National Center for Biotechnology Information (NCBI) (Zhang et al. 2000; Morgulis et al. 2008). The obtained sequences were submitted to GenBank. To illustrate the relationship between the sequences of the whiteflies obtained from Jordan and other whiteflies sequences from all over the world, a phylogenetic tree was constructed. The sequences of whiteflies from Jordan were aligned and trimmed to the same length beside other sequences of whiteflies from throughout the world obtained from the GenBank. Then the phylogenetic tree was built using Maximum Likelihood method based on the Tamura-Nei model (Tamura and Nei 1993).

\section{Results}

Ten species of whiteflies were morphologically identified in Jordan. As the aim of this study is to combine the morphological and molecular identification tools to identify the whitefly species in Jordan; the morphological identification was the main tool for identifying the whitefly species other than B. tabaci. According to the morphological classification of the whitefly species, nine different whitefly species were identified in addition to $B$. tabaci (Table 1). The identified species were Trialeurodes lauri (Signoret), Trialeurodes ricini (Misra), Aleyrodes singularis (Danzig), Aleurolobus niloticus (Priesner and Hosny), Aleurolobus olivinus (Silvestri), Acaudaleyrodes rachipora (Singh), Africaleurodes coffeacola (Dozier, 1934), Siphoninus phillyreae (Haliday) and Tetraleurodes neemani (Bink-Moenen, 1992). They belong to seven different genera. The two whitefly species Africaleurodes coffeacola and $T$. neemani had not been recorded before in Jordan.

Molecular and phylogenetic analysis. For the purpose of barcoding of the collected whitefly samples, $m t C O I$ gene was amplified and analysed. Around $816 \mathrm{bp}$ fragment of the $m t C O I$ gene was amplified for all the collected samples of whitefly species and B. tabaci species complex (Fig. 1A). Representative samples of the different whitefly species and B. tabaci were sent for sequencing. Additionally, this PCR product was subjected to CAPS for further analysis of $B$. tabaci samples.

CAPS and the bidirectional PCR for $m t C O I$ sequence revealed the presence of only MEAMI. In spite of the different hosts, geographical regions, and the time of collection; all the collected B. tabaci samples during the period 2009-2012 showed MEAM1 pattern in CAPS (Fig. 1B). The same results were confirmed by the bidirectional PCR, the second DNA marker used as it is presented (Fig. 1C).

After the morphological identification of the whitefly species that were collected from Jordan, the sequences of $m t C O I$ for some of these whiteflies -except $B$. tabaciwere submitted to GenBank under the accession numbers: 
KP418768-KP418780. Whereas representative samples of $B$. tabaci $m t C O I$ sequences were submitted to GenBank under the accession numbers: KC789925-KC789962. All of the $B$. tabaci samples showed high identity with MEAM1 putative species throughout the world.

To illustrate the relationship within the collected whiteflies samples from Jordan and the other related whiteflies from the world, two phylogenetic trees were constructed. The first tree illustrated the relationship among the different whitefly species from Jordan including $B$. tabaci species complex and the other related whitefly species from the world that are available in the GenBank (Fig. 2). The tree confirmed the results obtained from the morphological and molecular identifications. The second phylogenetic tree was constructed for the B. tabaci species complex only (Fig. 3). It showed that all the samples from Jordan are very closely related to the MEAM1 putative species from around the world such as MEAM1 from Japan, Morocco, and Cuba. This as well confirms that all the collected B. tabaci samples from Jordan are MEAM1.

\section{Discussion}

This study aimed to combine the classical morphological identification method of the different whitefly species with the molecular DNA barcoding method for faster and easier identification. Ten different whitefly species were identified mainly based on the morphology. This was due to the poor database of the $m t C O I$ that is available for the whitefly species other than B. tabaci in GenBank. The obtained sequences were submitted to GenBank, so that, in the future, they would be helpful for the purpose of whitefly identification.

Table 1. Updated whitefly species in Jordan, host plants, location and method(s) used in species identification.

\begin{tabular}{|c|c|c|c|c|}
\hline Whitefly species & Host & Location & $\begin{array}{c}\text { Accession No. } \\
\text { (GenBank) }\end{array}$ & $\begin{array}{l}\text { Identification } \\
\text { method }\end{array}$ \\
\hline Acaudaleyrodes rachipora & $\begin{array}{l}\text { Citrus limon (L.) Osbeck } \\
\text { Olea europaea L. }\end{array}$ & Amman & $\begin{array}{l}\text { KP418775 } \\
\text { KP418776 } \\
\text { KP418780 }\end{array}$ & $\begin{array}{l}\text { Morphology and } \\
\text { molecular }\end{array}$ \\
\hline Africaleurodes coffeacola & Ziziphus spina-christi (L.) Desf & Al-Balqa' & & Morphology \\
\hline Aleurolobus niloticus & Punica granatum L. & Al-Balqa` & $\begin{array}{l}\text { KP418772 } \\
\text { KP418773 }\end{array}$ & $\begin{array}{l}\text { Morphology and } \\
\text { molecular }\end{array}$ \\
\hline Aleurolobus olivinus & Olea europaea L. & Amman, Al-Balqa' & $\begin{array}{l}\text { KP418774 } \\
\text { KP418778 } \\
\text { KP418779 }\end{array}$ & $\begin{array}{l}\text { Morphology and } \\
\text { molecular }\end{array}$ \\
\hline Aleyrodes singularis & Lactuca serriola L. & Amman, AL-Balqa' & $\begin{array}{l}\text { KP418769 } \\
\text { KP418770 } \\
\text { KP418771 }\end{array}$ & $\begin{array}{l}\text { Morphology and } \\
\text { molecular }\end{array}$ \\
\hline Bemisia tabaci (MEAM1) & $\begin{array}{l}\text { Abelmoschus esculentus (L.) Moench } \\
\text { Althaea rosea } \text { L. } \\
\text { Brassica oleracea } \text { var. botrytis L. } \\
\text { Brassica oleracea } \text { var. capitata } \text { L. } \\
\text { Brugmansia } \text { sp. } \\
\text { Capsicum sp. } \\
\text { Citrullus lanatus (Thunb.) Matsum. \& } \\
\text { Nakai } \\
\text { Cucumis melo var. flexuosus (L.) Naudin } \\
\text { Cucumis sativus } \text { L. } \\
\text { Cucurbita pepo var. melopepo L. Harz. } \\
\text { Cucurbita pepo var. pepo L. } \\
\text { Euphorbia pulcherrima Willd. ex Klotzsch } \\
\text { Gossypium } \text { sp. } \\
\text { Helianthus annums } \text { L. } \\
\text { Lagenaria siceraria (Molina) Standl. } \\
\text { Lantana camara } \text { L. } \\
\text { Lycopersicon esculentum Mill. } \\
\text { Ocimum basilicum } \text { L. } \\
\text { Ricinus communis L. } \\
\text { Solanum melongena } \text { L. } \\
\text { Solanum tuberosum L. }\end{array}$ & $\begin{array}{l}\text { Amman, AL-Balqa', } \\
\text { Al-Mafraq, Jerash, } \\
\text { Jordan Valley, } \\
\text { Ma`an, Madaba }\end{array}$ & $\begin{array}{l}\text { КC789925- } \\
\text { КC789962 }\end{array}$ & $\begin{array}{l}\text { Morphology and } \\
\text { molecular }\end{array}$ \\
\hline Siphoninus phillyreae & Punica granatum $\mathrm{L}$. & Al-Balqa` & & Morphology \\
\hline Tetraleurodes neemani & Punica granatum L. & Amman, Al-Balqa` & & Morphology \\
\hline Trialeurodes lauri & Arbutus andrachne L. & Jerash & KP418768 & $\begin{array}{l}\text { Morphology and } \\
\text { molecular }\end{array}$ \\
\hline Trialeurodes ricini & Ricinus communis L. & Al-Balqa` & KP418777 & $\begin{array}{l}\text { Morphology and } \\
\text { molecular }\end{array}$ \\
\hline
\end{tabular}



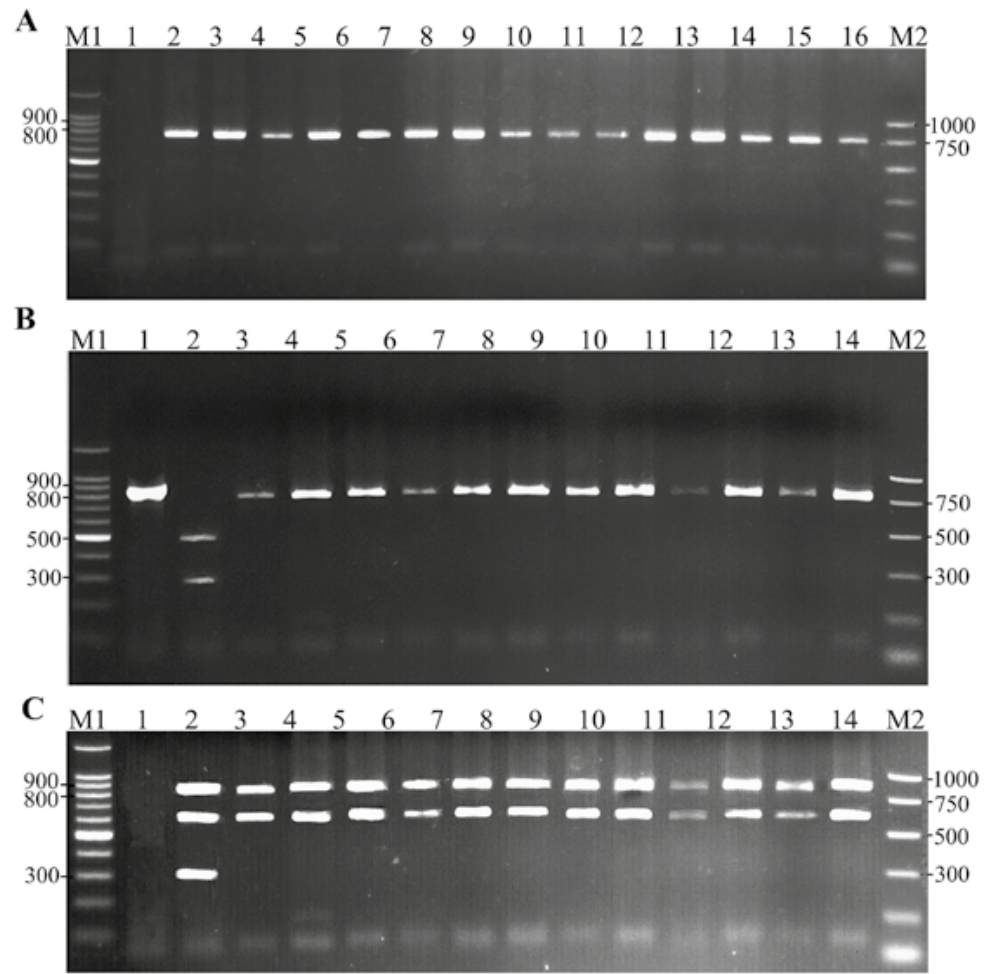

Figure 1. Amplification and analysis of $m t C O I$. A. Amplification of $816 \mathrm{bp}$ of $m t C O I$ gene for the whitefly species including Bemisia tabaci species complex. Sample 1, negative control; 2, positive control; 3-16, amplified part of $m t C O I$ gene. B. CAPS applied on the amplified $m t C O I$ gene $(816$ bp) for B. tabaci species complex. Sample 1, undigested PCR product; 2, CAPS pattern of MED reference; 3, CAPS pattern of MEAM1 reference; 4-14, samples of B. tabaci from Jordan. C. The bidirectional PCR analysis. Sample 1, negative control; 2, MED reference; 3, MEAM1 reference; 4-14, samples of B. tabaci from Jordan. Samples were analysed on $1 \%$ agarose gel stained with 0.5 $\mu \mathrm{g} / \mathrm{ml}$ of ethidium bromide M1, $100 \mathrm{bp}$ DNA ladder; M2, PCR markers.

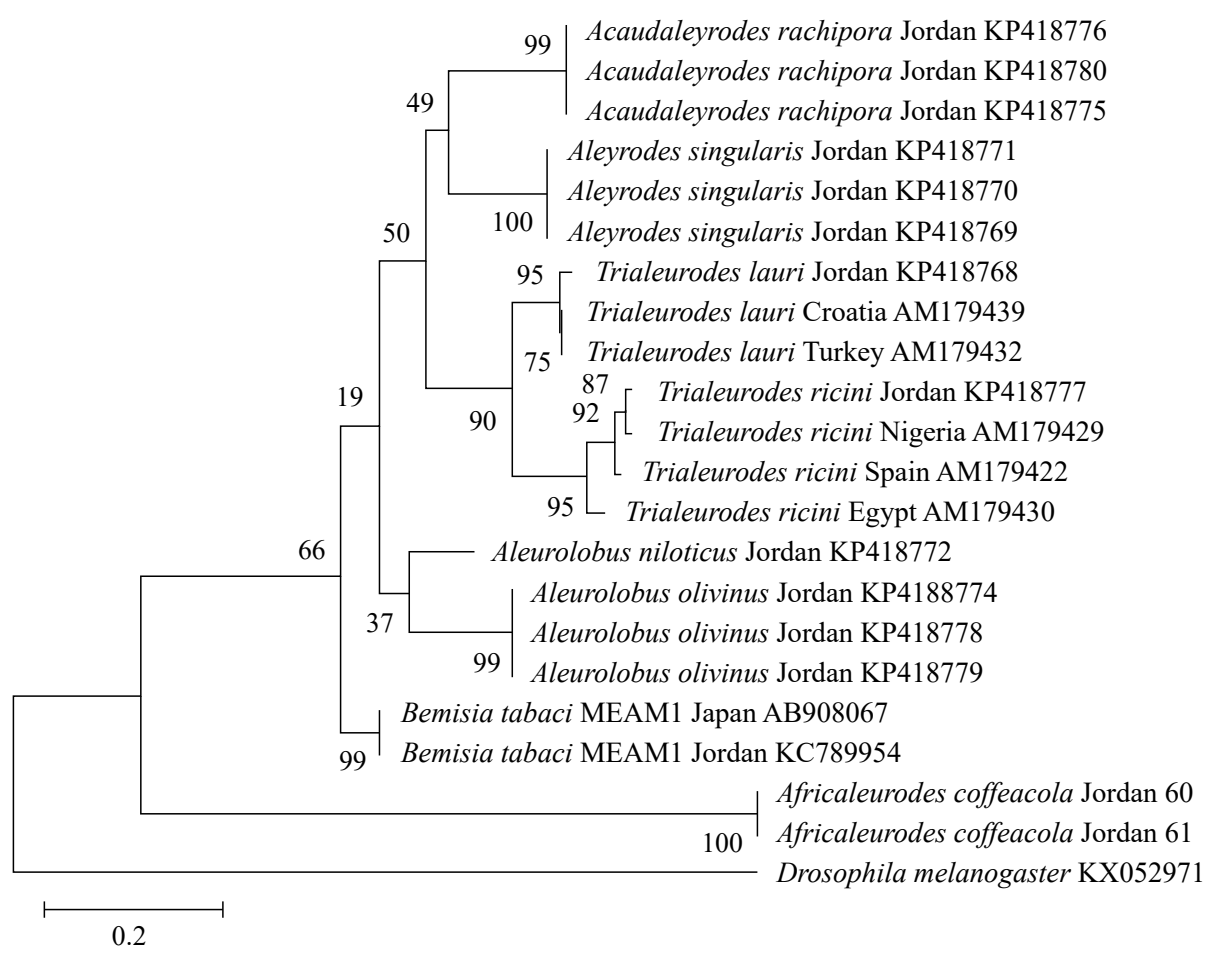

Figure 2. Phylogenetic tree analysis by Maximum Likelihood method based on the Tamura-Nei model for a part of $m t C O I$ gene for different whitefly species collected from Jordan and other parts around the world, Drosophila melanogaster (Meigen,1830) was used as an outgroup taxon. The number at the nodes represents the bootstrapping value and the scale represents the genetic distance. The analyses were conducted using MEGA-X (Kumar et al. 2018). 


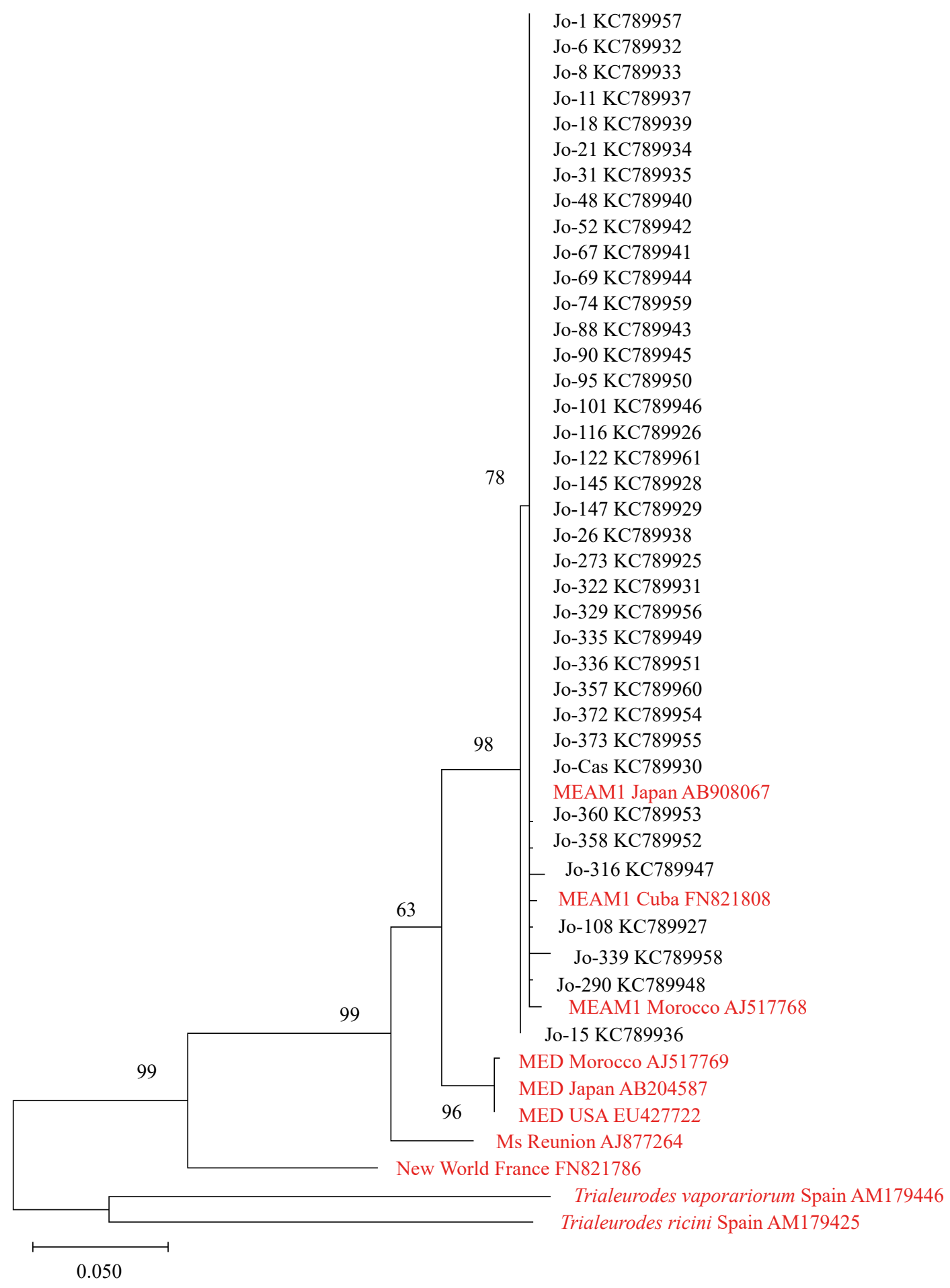

Figure 3. Phylogenetic analysis by Maximum Likelihood method based on the Tamura-Nei model, for a part of $m t C O I$ gene for Bemisia tabaci samples collected from Jordan indicated with (Jo-), the other B. tabaci from the world are colored in red. Trialeurodes vaporariorum and Trialeurodes ricini were used as outgroup taxa. The number at the nodes represents the bootstrapping value and the scale represents the genetic distance. The analyses were conducted using MEGA-X (Kumar et al. 2018).

Of the ten species, two species were recorded in Jordan for the first time; these species were T. neemani and Africaleurodes coffeacola. T. neemani was also reported in Palestine/ Israel (Martin and Mound 2007), China and Iran (Wang et al. 2016). Whilist, Africaleurodes coffeacola has been reported in Nigeria (Oyelade and Ayansola 2015) and Congo (Martin and Mound 2007).
This study especially focused on studying the genetic diversity of the invasive whitefly $B$. tabaci species complex using three techniques based on $m t C O I$ gene sequence (bidirectional PCR, CAPS, and sequencing). In the literatures, MEAM1 and New World putative species have been identified in Jordan using only RAPD technique (Sharaf and Hasan 2003). However, in this study the samples collected during 
three consecutive years on more than 23 different hosts and from different geographical regions in Jordan confirmed the presence of only MEAM1. It is worth mentioning that the samples were collected from the same places where the New World had been reported earlier as well as the fact that MEAM1 putative species is not new to Jordan as it is known to originate from this area (Broadbent et al. 1989; Cheek and Macdonald 1994; De Barro et al. 2011). MEAM1 putative species are polyphagous, and the females are known for their high fecundity and lower immature mortality (Brown 2007; Costa and Brown 1991; Horowitz et al. 2005; Zhang et al. 2005); this may help this putative species to displace any other species present. In addition to the previous points, the agricultural practices in Jordan could favour the dominance of MEAM1 and the displacement of New World putative species.

\section{Conclusions}

Nine species of whiteflies in addition to B. tabaci were identified in Jordan. Identification was primarily based on the morphology and supported by the sequences of the mtCOI gene. Two species were reported in Jordan for the first time. Depending on the results, it is important to evaluate the damage caused especially by the newly reported species in Jordan, their hosts and if they could transmit any plant viruses. Also, this study was concerned with updating the status of $B$. tabaci species complex in Jordan to help in designing effective control methods. The results confirmed the presence of only MEAM1 putative species. As a result, it is important to consider the control methods of this pest, since MEAM1 is an invasive pest, that resists many insecticides and is a vector for many important plant viruses.

\section{Acknowledgement}

The authors acknowledge Prof. Dan Gerling for the morphological identification of the whiteflies, Dr Rami Horowitz for providing us with reference samples for MEAM1 and MED, and Dr. Fatima AlHaj-Ahmad and Dr. Wafa'a Odeh for their help in measuring the DNA concentration and sample collection.

\section{Literature cited}

ALLAWI, T. R. 1994. Whitefly species in Jordan. Arab Journal Plant Protection 12 (1): 30-32.

BARINAGA, M. 1993. Is devastating whitefly invader really a new species? Science 259 (5091): 30-31. https://doi.org/10.1126/ science. 8418492

BING, X. L.; RUAN, Y. M.; RAO, Q.; WANG, X. W.; LIU, S. S. 2012. Diversity of secondary endosymbionts among different putative species of the whitefly Bemisia tabaci. Insect Science 20 (2): 194-206. https://doi.org/10.1111/j.1744-7917.2012.01522.x

BOYKIN, L. M. 2014. Bemisia tabaci nomenclature: lessons learned. Pest Management Science 70 (10): 1454-1459. https://doi. org/10.1002/ps.3709

BOYKIN, L. M.; SHATTERS JR, R. G.; ROSELL, R. C.; McKENZIE, C. L.; BAGNALL, R. A.; DE BARRO, P.; FROHLICH, D. R. 2007. Global relationships of Bemisia tabaci (Hemiptera: Aleyrodidae) revealed using Bayesian analysis of mitochondrial COI DNA sequences. Molecular Phylogenetic and Evolution 44 (3): 1306-1319. https://doi.org/10.1016/j.ympev.2007.04.020

BOYKIN, L. M.; ARMSTRONG, K. F.; KUBATKO, L.; DE BARRO, P. 2012. Species delimitation and global biosecurity.
Evolutionary Bioinformatics 8: 1-37. https://doi.org/10.4137/ EBO.S8532

BROADBENT, A. B.; FOOTTIT, R. G.; MURPHY, G. D. 1989. Sweet potato whitefly Bemisia tabaci (Gennadius) (Homoptera: Aleyrodidae), a potential insect pest in Canada. Canadian Entomology 121 (11): 1027-1028. https://doi.org/10.4039/ Ent1211027-11

BROWN, J. K. 2007. The Bemisia tabaci complex: genetic and phenotypic variation and relevance to TYLCV-vector interactions. pp. 25-56. In: Czosnek, H. (Ed.). Tomato yellow leaf curl virus disease. Springer. Jerusalem, Israel. 447 p. https://doi. org/10.1007/978-1-4020-4769-5_3

BROWN, J. K.; FROHLICH, D. R.; ROSELL, R. C. 1995a. The sweet potato or silverleaf whiteflies: biotypes of Bemisia tabaci or a species complex? Annual Review of Entomology 40 (1): 511-534. https://doi.org/10.1146/annurev.en.40.010195.002455

BROWN, J. K.; COATS, S. A.; BEDFORD, I. D.; MARKHAM, P. G.; BIRD, J.; FROHLICH, D. R. 1995b. Characterization and distribution of esterase electromorphs in the whitefly, Bemisia tabaci (Genn.) (Homoptera: Aleyrodidae). Biochemical Genetics 33: 205-214. https://doi.org/10.1007/BF02401851

BYRNE, D. N.; BELLOWS JR, T. S. 1991. Whitefly biology. Annual Review Entomology 36 (1): 431-457. https://doi.org/10.1146/ annurev.en.36.010191.002243

CENIS, J. L.; PEREZ, P.; FERERES, A. 1993. Identification of aphid (Homoptera: Aphididae) species and clones by random amplified polymorphic DNA. Annals of the Entomological Society of America 86 (5): 545-550. https://doi.org/10.1093/aesa/86.5.545

CERVERA, M. T.; CABEZAS, J. A.; SIMON, B.; MARTINEZ-ZAPATER, J. M.; BEITIA, F.; CENIS, J. L. 2000. Genetic relationships among biotypes of Bemisia tabaci (Hemiptera: Aleyrodidae) based on AFLP analysis. Bulletin of Entomological Research 90 (5): 391-396. https://doi.org/10.1017/S0007485300000523

CHEEK, S.; MACDONALD, O. 1994. Statutory controls to prevent the establishment of Bemisia tabaci in the United Kingdom. Pest Science 42 (2): 135-142.

COSTA, H. S.; BROWN, J. K. 1991. Variation in biological characteristics and esterase patterns among populations of Bemisia tabaci, and the association of one population with silverleaf symptom induction. Entomologia Experimentalis et Applicata 61 (3): 211-219. https://doi.org/10.1111/j.1570-7458.1991. tb01553.x

DE BARRO, P. J.; DRIVER, F.; TRUEMAN, J. W. H.; CURRAN, J. 2000. Phylogenetic relationships of world populations of Bemisia tabaci (Gennadius) using ribosomal ITS1. Molecular Phylogenetic and Evolution 16 (1): 29-36. https://doi. org/10.1006/mpev.1999.0768

DE BARRO, P. J.; LIU, S. S.; BOYKIN, L. M.; DINSDALE, A. B. 2011. Bemisia tabaci: a statement of species status. Annual Review of Entomology 56: 1-19. https://doi.org/10.1146/annurev-ento-112408-085504

DINSDALE, A.; COOK, L.; RIGINOS, C.; BUCKLEY, Y. M.; DE BARRO, P. 2010. Refined global analysis of Bemisia tabaci (Gennadius) (Hemiptera: Sternorrhyncha: Aleyrodidae) mitochondrial CO1 to identify species level genetic boundaries. Annals of the Entomological Society of America 103 (2): 196208. https://doi.org/10.1603/AN09061

EUROPEAN AND MEDITERRANEAN PLANT PROTECTION ORGANIZATION. 2004. Bemisia tabaci. Bulletin OEPP/ EPPO Bulletin 34: 281-288. https://doi.org/10.1111/j.13652338.2004.00729.x

FROHLICH, D. R.; TORRES-JEREZ, I.; BEDFORD, I. D.; MARKHAM, P. G.; BROWN, J. K. 1999. A phylogeographical analysis of the Bemisia tabaci species complex based on mitochondrial DNA markers. Molecular Ecology 8 (10): 1683-1691. https://doi.org/10.1046/j.1365-294x.1999.00754.x

GAMARRA, H. A.; FUENTES, S.; MORALES, F. J.; GLOVER, R.; MALUMPHY, C.; BARKER, I. 2010. Bemisia afersensu lato, a 
vector of Sweet potato chlorotic stunt virus. Plant Diseases 94 (5): 510-514. https://doi.org/10.1094/PDIS-94-5-0510

GHAHARI, H.; ABD-RABOU, S.; ZAHRADNIK, J.; OSTOVAN, H. 2009. Annotated catalogue of whiteflies (Hemiptera: Sternorrhyncha: Aleyrodidae) from Arasbaran, Northwestern Iran. Journal of Entomology and Nematology 1 (1): 007-018. https:// doi.org/10.5897/JEN.9000004

GHANIM, M.; KONTSEDALOV, S. 2007. Gene expression in pyriproxyfen-resistant Bemisia tabaci Q biotype. Pest Management Science: formerly Pesticide Science. 63 (8): 776-783. https://doi. org/10.1002/ps.1410

HOROWITZ, A. R.; DENHOLM, I.; GORMAN, K.; CENIS, J. L.; KONTSEDALOV, S.; ISHAAYA, I. 2003. Biotype Q of Bemisia tabaci identified in Israel. Phytoparasitica 31: 94-98. https://doi. org/10.1007/BF02979772

HOROWITZ, A. R.; KONTSEDALOV, S.; KHASDAN, V.; ISHAAYA, I. 2005. Biotypes B and Q of Bemisia tabaci and their relevance to neonicotinoid and pyriproxyfen resistance. Archives of Insect Biochemistry and Physiology 58 (4): 216-225. https://doi. org/10.1002/arch.20044

IDRISS, M.; ABDALLAH, N.; AREF, N.; HARIDY, G.; MADKOUR, M. 1997. Biotypes of the castor bean whitefly Trialeurodes ricini (Misra) (Hom., Aleyrodidae) in Egypt: biochemical characterization and efficiency of geminivirus transmission. Journal of Applied Entomology 121 (1-5): 501-509. https://doi. org/10.1111/j.1439-0418.1997.tb01440.x

JONES, D. R. 2003. Plant viruses transmitted by whiteflies. European Journal of Plant Pathology 109 (3): 195-219. https://doi. org/10.1023/A:1022846630513

KHASDAN, V.; LEVIN, I.; ROSNER, A.; MORIN, S.; KONTSEDALOV, S.; MASLENIN, L.; HOROWITZ, A. R. 2005. DNA markers for identifying biotypes $\mathrm{B}$ and $\mathrm{Q}$ of Bemisia tabaci (Hemiptera: Aleyrodidae) and studying population dynamics. Bulletin of Entomological Research 95 (6): 605-613. https://doi. org/10.1079/BER2005390

KIRK, A. A.; LACEY, L. A.; BROWN, J. K.; CIOMPERLIK, M. A.; GOOLSBY, J. A.; VACEK, D. C.; WENDEL, L. E.; NAPOMPETH, B. 2000. Variation in the Bemisia tabaci species complex (Hemiptera: Aleyrodidae) and its natural enemies leading to successful biological control of Bemisia biotype B in the USA. Bulletin of Entomological Research 90 (4): 317-327. https://doi. org/10.1017/S0007485300000444

KO, C.; CHANG, S.; HU, C. 2005. Survey of whiteflies and their transmission of plant viruses in Taiwan. Taipei: ASPAC Food and Fertilizer Technology Centre. https://www.fftc.org.tw/htmlarea_file/library/20110712181840/eb571.pdf

KUMAR, S.; STECHER, G.; LI, M.; KNYAZ, C.; TAMURA, K. 2018. MEGA X: Molecular Evolutionary Genetics Analysis across Computing Platforms. Molecular Biology and Evolution 35 (6): 1547-1549. https://doi.org/10.1093/molbev/msy096

LIU, S.; COLYIN, J.; DE BARRO, P. J. 2012. Species concepts as applied to the whitefly Bemisia tabaci systematics: how many species are there? Journal of Integrative Agriculture 11 (2): 176186. https://doi.org/10.1016/S2095-3119(12)60002-1

LIU, G.; MA, H.; XIE, H.; XUAN, N.; GUO, X.; FAN, Z.; RAJASHEKAR, B.; ARNAUD, P.; OFFMANN, B.; PICIMBON, J-F. 2016. Biotype characterization, developmental profiling, insecticide response and binding property of Bemisia tabaci chemosensory proteins: role of CSP in insect defense. PLoS ONE 11 (5): e0154706. https://doi.org/10.1371/journal.pone.0154706

LUO, C.; YAO, Y.; WANG, R.; YAN, F.; HU, D.; ZHANG, Z. 2002. The use of mitochondrial cytochrome oxidase I (mt CO I) gene sequences for the identification of biotypes of Bemisia tabaci (Gennadius) in China. Acta Entomologica Sinica 45 (6): 757 763. https://europepmc.org/article/cba/381891

MARTIN, J. H. 2004. Whiteflies of Belize (Hemiptera: Aleyrodidae). Part 1-introduction and account of the subfamily Aleurodicinae Quaintance \& Baker. Zootaxa 681 (1): 1-119. https://doi. org/10.11646/zootaxa.681.1.1
MARTIN, J. H.; MOUND, L. A. 2007. An annotated check list of the world's whiteflies (Insecta: Hemiptera: Aleyrodidae). Zootaxa 1492 (1): 1-84. https://doi.org/10.11646/zootaxa.1492.1.1

MLYNAREK, J. J., LABBÉ, R. M. 2018. Trialeurodes abutiloneus (Haldeman) (Hemiptera: Aleyrodidae), a species long present but never officially recorded in Canada. The Canadian Entomologist 150 (4): 532-538. https://doi.org/10.4039/tce.2018.26

MORGULIS, A.; COULOURIS, G.; RAYTSELIS, Y.; MADDEN, T. L.; AGARWALA, R.; SCHAFFER, A. A. 2008. Database indexing for production MegaBLAST searches. Bioinformatics 24 (16): 1757-1764. https://doi.org/10.1093/bioinformatics/btn554

NAUEN, R.; DENHOLM, I. 2005. Resistance of insect pests to neonicotinoid insecticides: current status and future prospects. Archive of Insect Biochemistry and Physiology 58 (4): 200-215. https://doi.org/10.1002/arch.20043

NAUEN, R.; STUMPF, N.; ELBERT, A. 2002. Toxicological and mechanistic studies on neonicotinoid cross resistance in Q-type Bemisia tabaci (Hemiptera: Aleyrodidae). Pest Management Science 58 (9): 868-875. https://doi.org/10.1002/ps.557

NAVAS-CASTILLO, J.; FIALLO-OLIVE, E.; SANCHEZ-CAMPOS, S. 2011. Emerging virus diseases transmitted by whiteflies. Annual Review of Phytopathology 49: 219-248. https://doi. org/10.1146/annurev-phyto-072910-095235

OLIVEIRA, M. R. V.; HENNEBERRY, T. J.; ANDERSON, P. 2001. History, current status, and collaborative research projects for Bemisia tabaci. Crop Protection 20 (9): 709-723. https://doi. org/10.1016/S0261-2194(01)00108-9

OYELADE, O. J.; AYANSOLA, A. A. 2015. Diversity and distribution of whiteflies in south-western Nigeria. African Crop Science Journal 23 (2): 135-149. https://www.ajol.info/index.php/acsj/ article/view/117735

POLSTON, J. E.; DE BARRO, P.; BOYKIN, L. M. 2014. Transmission specificities of plant viruses with the newly identified species of the Bemisia tabaci species complex. Pest Management Science 70 (10): 1547-1552. https://doi.org/10.1002/ps.3738

PRABHAKER, N.; COUDRIET, D. L.; TOSCANO, N. C. 1988. Effect of synergists on organophosphate and permethrin resistance in sweet potato whitefly (Homoptera: Aleyrodidae). Journal of Economic Entomology 81 (1): 34-39. https://doi.org/10.1093/ jee/81.1.34

ROSELL, R. C.; BEDFORD, I. D.; FROHLICH, D. R.; GILL, R. J.; BROWN, J. K.; MARKHAM, P. G. 1997. Analysis of morphological variation in distinct populations of Bemisia tabaci (Homoptera: Aleyrodidae). Annals of Entomological Society of America 90 (5): 575-589. https://doi.org/10.1093/aesa/90.5.575

SHARAF, N.; ALLAWI, T. F. 1980. Studies on whiteflies on tomato in Jordan Valley I. Host range of the tobacco whitefly Bemisia tabaci Genn. (Homoptera: Aleyrodidae). Dirasat 7 (1): 53-63.

SHARAF, N.; HASAN, H. 2003. The identification of two biotypes of Bemisia tabaci in Jordan. Dirasat 30 (1): 101-108. https:// www.cabdirect.org/cabdirect/abstract/20033042084

SHI, X.; TANG, X.; ZHANG, X.; ZHANG, D.; LI, F.; YAN, F.; ZHANG, Y.; ZHOU, X.; LIU, Y. 2018. Transmission efficiency, preference and behavior of Bemisia tabaci MEAM1 and MED under the influence of Tomato chlorosis virus. Frontiers in Plant Science 8: 1-9. https://doi.org/10.3389/fpls.2017.02271

SHUKLA, A. K.; UPADHYAY, S. K.; MISHRA, M.; SAURABH, S.; SINGH, R.; SINGH, H.; THAKUR, N.; RAI, P.; PANDEY, P.; HANS, A. L.; SRIVASTAVA, S. 2016. Expression of an insecticidal fern protein in cotton protects against whitefly. Nature Biotechnology 34 (10): 1046-1051. https://doi.org/10.1038/ nbt.3665

SUN, D. B.; XU, J.; LUAN, J. B.; LIU, S. S. 2011. Reproductive incompatibility between the B and Q biotypes of the whitefly Bemisia tabaci in China: genetic and behavioural evidence. Bulletin of Entomological Research 101 (2): 211-220. https://doi. org/10.1017/S0007485310000416 
TAMURA, K.; NEI, M. 1993. Estimation of the number of nucleotide substitutions in the control region of mitochondrial DNA in humans and chimpanzees. Molecular Biology and Evolution 10 (3): 512-526. https://doi.org/10.1093/oxfordjournals.molbev. a040023

TAY, W. T.; EVANS, G. A.; BOYKIN, L. M.; DE BARRO, P. J. 2012. Will the real Bemisia tabaci please stand up? PLoS One 7 (11): e50550. https://doi.org/10.1371/journal.pone.0050550

TSAGKARAKOU, A.; TSIGENOPOULOS, C. S.; GORMAN, K.; LAGNEL, J.; BEDFORD, I. D. 2007. Biotype status and genetic polymorphism of the whitefly Bemisia tabaci (Hemiptera: Aleyrodidae) in Greece: mitochondrial DNA and microsatellites. Bulletin of Entomological Research 97 (1): 29-40. https://doi. org/10.1017/S000748530700466X

WANG, X-W.; LUAN, J-B.; LI, J-M.; SU, Y-L.; XIA, J.; LIU, S-S. 2011. Transcriptome analysis and comparison reveal divergence between two invasive whitefly cryptic species. BMC Genomics 12 (1): 1-12. https://doi.org/10.1186/1471-2164-12-458

WANG, H-L.; YANG, J.; BOYKIN, L. M.; ZHAO, Q-Y.; LI, Q.; WANG, X-W.; LIU, S-S. 2013. The characteristics and expression profiles of the mitochondrial genome for the Mediterranean species of the Bemisia tabaci complex. BMC Genomics. 14 (1): 1-15. https://doi.org/10.1186/1471-2164-14-401

WANG, J.; DU, Y.; XU, Z. 2016. Six newly recorded species of whitefly (Hemiptera: Aleyrodidae) from China. Zoological Systematics 41 (4): 427-438. https://doi.org/10.11865/zs.201647

WATANABE, L. F. M.; BELLO, V. H.; DE MARCHI, B. R.; SILVA, F. B.; FUSCO, L. M.; SARTORI, M. M. P.; PAVAN, M. A.; KRAUSE-SAKATE, R. 2019. Performance and competitive displacement of Bemisia tabaci MEAM1 and MED cryptic species on different host plants. Crop Protection 124: 104860. https:// doi.org/10.1016/j.cropro.2019.104860

WU, X.; LI, Z.; HU, D.; SHEN, Z. 2003. Identification of Chinese populations of Bemisia tabaci (Gennadius) by analyzing ribosomal ITS1 sequence. Progress in Natural Science 13 (4): 276-281. https://doi.org/10.1080/10020070312331343530
XU, J.; DE BARRO, P. J.; LIU, S. S. 2010. Reproductive incompatibility among genetic groups of Bemisia tabaci supports the proposition that the whitefly is a cryptic species complex. Bulletin of Entomological Research 100 (3): 359-366. https:// doi.org/10.1017/S0007485310000015

YANG, N.; XIE, W.; YANG, X.; WANG, S.; WU, Q.; LI, R.; PAN, H.; LIU, B.; SHI, X.; FANG, Y.; XU, B.; ZHOU, X.; ZHANG, Y. 2013. Transcriptomic and proteomic responses of sweet potato whitefly, Bemisia tabaci, to thiamethoxam. PLoS One 8 (5): e61820. https://doi.org/10.1371/journal.pone.0061820

YANG, J.; XIE, W.; LIU, B.; WANG, S.; WU, Q.; HE, Y.; ZHANG, Y; JIAO, X. 2020. Phenolics, rather than glucosinolates, mediate host choice of Bemisia tabaci MEAM1 and MED on five cabbage genotypes. Journal of Applied Entomology 144 (4): 287-296. https://doi.org/10.1111/jen.12737

ZHANG, Z.; SCHWARTZ, S.; WAGNER, L.; MILLER, W. 2000. A greedy algorithm for aligning DNA sequences. Journal of Computational Biology 7 (1-2): 203-214. https://doi. org/10.1089/10665270050081478

ZHANG, L. P.; ZHANG, Y. J.; ZHANG, W. J.; WU, Q. J.; XU, B. Y.; CHU, D. 2005. Analysis of genetic diversity among different geographical populations and determination of biotypes of Bemisia tabaci in China. Journal of Applied Entomology 129 (3): 121-128. https://doi.org/10.1111/j.1439-0418.2005.00950.x

\section{Origin and funding}

The present research was self-funded project.

\section{Author contribution}

Ihab Ghabeish: samples collection, morphological identification and writing.

Mais Sweiss: molecular identification, results analysis and writing.

Ghandi Anfoka: samples collection and sequencing of the samples. 